\title{
Gambaran Hiperurisemia pada Subyek Keturunan Hipertensi dan Tidak Keturunan Hipertensi
}

\author{
Catrien Berhandus, ${ }^{1}$ Jeffrey A. Ongkowijaya J, ${ }^{2}$ Adeodata M. C. Kaparang ${ }^{2}$
}

\author{
${ }^{1}$ Program Pendidikan Dokter Spesialis Ilmu Penyakit Dalam Fakultas Kedokteran Universitas \\ Sam Ratulangi, Manado, Indonesia \\ ${ }^{2}$ Divisi Reumatologi KSM/Bagian Ilmu Penyakit Dalam Fakultas Kedokteran Universitas \\ Sam Ratulangi, Manado, Indonesia \\ Email: catrieninterna2017@gmail.com
}

\begin{abstract}
Hypertension is one of the most common cardiovascular diseases worldwide. Hyperuricemia is considered if serum uric acid level $>7 \mathrm{mg} / \mathrm{dl}$ in men and $>6 \mathrm{mg} / \mathrm{dl}$ in women. This condition is not only associated with gout but has other associations with various diseases such as cardiovascular disease, systemic inflammation, endothelial dysfunction, and hypertension. This study was aimed to obtain the description of serum uric acid levels among people who had family history of hypertension and those who did not. This was a descriptive and observational study with a cross-sectional design. Samples were obtained at Prof. dr. R. D. Kandou Manado by using consecutive sampling, and then were divided into two groups, with and without family history of hypertension; each of 20 people. Of the group with family history of hypertension, 12 were male $(60 \%)$ and 8 were female $(40 \%)$, while of the other group, 10 were male (50\%) and 10 were female $(50 \%)$. Based on serum uric acid levels, 6 $(30 \%)$ of the group with family history of hypertension had hyperuricemia, while $3(15 \%)$ of the other group had hyperuricemia; all of them were male. In conclusion, people with family history of hypertension had hyperuricemia more frequently compared to those without family history of hypertension, with dominant male sex in both groups.
\end{abstract}

Keywords: uric acid; family history of hypertension; hyperuricemia

\begin{abstract}
Abstrak: Hipertensi masih merupakan salah satu penyakit kardiovaskular yang paling umum di seluruh dunia. Hiperurisemia ditetapkan bila kadar serum asam urat $>7 \mathrm{mg} / \mathrm{dl}$ pada laki-laki dan $>6 \mathrm{mg} / \mathrm{dl}$ pada perempuan. Hiperurisemia tidak hanya berhubungan dengan gout tetapi memiliki hubungan dengan berbagai penyakit seperti penyakit kardiovaskular, inflamasi sistemik, disfungsi endotel, dan hipertensi. Penelitian ini bertujuan untuk mendapatkan gambaran asam urat pada subyek keturunan hipertensi dan tidak keturunan hipertensi. Jenis penelitian ialah observasional deskriptif dengan desain potong lintang. Sampel diperoleh di RSUP Prof. Dr. R. D. Kandou Manado menggunakan consecutive sampling dan dibagi atas dua kelompok, yaitu keturunan hipertensi dan tidak keturunan hipertensi dari hasil anamnesis; masing-masing terdiri dari 20 orang. Dari kelompok keturunan hipertensi didapatkan 12 subyek laki-laki (60\%) dan 8 perempuan (40\%), sedangkan dari kelompok lainnya sebanyak 10 subyek laki-laki (50\%) dan 10 subyek perempuan (50\%). Berdasarkan kadar asam urat, dari kelompok keturunan hipertensi sebanyak 6 orang (30\%) mengalami hiperurisemia, sedangkan pada kelompok lainnya sebanyak 3 orang (15\%) mengalami hiperurisemia. Semua subyek pada kedua kelompok yang mengalami hiperurisemia berjenis kelamin laki-laki. Simpulan penelitian ini ialah subyek keturunan hipertensi lebih banyak mengalami hiperurisemia dibandingkan subyek tidak keturunan hipertensi, dengan jenis kelamin laki-laki dominan pada kedua kelompok.
\end{abstract}

Kata kunci: asam urat; keturunan hipertensi; hiperurisemia 


\section{PENDAHULUAN}

Hipertensi merupakan salah satu penyakit kardiovaskular yang paling umum dan paling banyak didapatkan pada masyarakat dan merupakan masalah kesehatan utama baik di negara maju maupun negara berkembang. ${ }^{1,2}$ Menurut WHO, sekitar 1.13 miliar orang di seluruh dunia memiliki hipertensi dan dua per tiga di antaranya berasal dari negara dengan pendapatan rendah hingga menengah. Pada tahun 2015, satu dari empat laki-laki dan satu dari lima perempuan memiliki hipertensi. ${ }^{3}$ Prevalensi hipertensi di Indonesia sendiri meningkat menurut Riskesdas tahun 2013 hingga tahun 2018 yaitu dari $25,8 \%$ menjadi $34,11 \%$.

Asam urat merupakan produk akhir dari metabolisme purin yang dikatalisasi oleh xanthin oxidase pada manusia. ${ }^{6}$ Pada awalnya asam urat dikenal sebagai anti-oksidan mayor dengan keuntungan efek anti aterosklerotik. Ternyata hal ini sangat berbeda dengan penelitian selama dua dekade terakhir yang mengusulkan bahwa asam urat memiliki peran sebagai salah satu faktor risiko terjadinya penyakit kardiovaskular. ${ }^{7}$ Secara umum, kadar serum asam urat $>7$ $\mathrm{mg} / \mathrm{dl}$ pada laki-laki dan $>6 \mathrm{mg} / \mathrm{dl}$ pada perempuan dianggap sebagai hiperurisemia dalam aspek klinis. Faktor risiko terjadinya hiperurisemia meliputi konsumsi alkohol, diet tinggi lemak dan karbohidrat olahan, serta obat-obatan diuretik dan angiotensin converting enzyme antagonist. ${ }^{8}$

Hiperurisemia tidak hanya berhubungan dengan gout tetapi juga dengan berbagai penyakit seperti penyakit kardiovaskular, inflamasi sistemik, disfungsi endotel, dan hipertensi. Mekanisme hiperurisemia dalam menyebabkan hipertensi belum sepenuhnya diketahui. Hiperurisemia dapat menyebabkan gangguan pada sel endotel dan mengaktivasi sistem renin angiotensin secara langsung. Asam urat dalam sel endotel pembuluh darah menyebabkan terjadi reaksi inflamasi, penurunan endothelial nitric oxide synthase (eNOS), peningkatan reactive oxygen species (ROS), dan penurunan produksi nitrik oksida (NO). Selain menyebabkan gangguan pada endotel, asam urat dapat menyebabkan proliferasi sel otot polos vaskular melalui aktivasi platelet derived growth factor (PDGF). Bersama dengan angiotensin II, gangguan pada endotel dan proliferasi otot polos asam urat menyebabkan terjadinya hipertensi. $6,9,10$

Mengingat prevalensi hipertensi dan hiperurisemia yang masih tinggi di Sulawesi Utara maka penulis terdorong untuk mendapatkan gambaran kadar asam urat pada subyek keturunan hipertensi dan yang bukan keturunan hipertensi.

\section{METODE PENELITIAN}

Penelitian ini dilakukan di RSUP Prof. Dr. R. D. Kandou Manado dengan rentang waktu dari bulan Januari 2020 sampai Maret 2020. Jenis penelitian ialah observasional deskriptif dengan desain potong lintang. Sampel diperoleh dengan menggunakan tehnik consecutive sampling.

Subyek penelitian ialah keluarga pasien yang dirawat di RSUP Prof. Dr. R. D. Kandou, terdiri dari yang keturunan hipertensi dan yang tidak keturunan hipertensi, diperoleh melalui anamnesis; kesemuanya tidak menyandang hipertensi pada saat penelitian berlangsung (tekanan darah sistolik <130 mmHg dan tekanan darah diastolik $<80 \mathrm{mmHg}$ ). Hiperurisemia ditetapkan bila kadar serum asam urat $>7 \mathrm{mg} / \mathrm{dl}$ pada lakilaki dan $>6 \mathrm{mg} / \mathrm{dl}$ pada perempuan.

\section{HASIL PENELITIAN}

Pada penelitian ini didapatkan 20 subyek keturunan hipertensi dan 20 subyek tidak keturunan hipertensi yang diperoleh melalui anamnesis dengan rentang usia 1840 tahun. Tabel 1 memperlihatkan dari 20 subyek keturunan hipertensi terdapat sebanyak 12 laki-laki (60\%) dan delapan perempuan (40\%), sedangkan dari 20 subyek tidak keturuanan hipertensi sebanyak 10 laki-laki (50\%) dan 10 perempuan (50\%).

Tabel 2 memperlihatkan bahwa berdasarkan kadar asam urat, dari subyek keturunan hipertensi sebanyak enam orang (30\%) mengalami hiperurisemia, sedangkan pada subyek tidak keturunan hipertensi sebanyak tiga orang (15\%). Semua subyek pada kedua kelompok yang mengalami hiperurisemia berjenis kelamin laki-laki. 
Tabel 1. Distribusi subyek berdasarkan jenis kelamin

\begin{tabular}{ccc}
\hline Jenis & \multicolumn{2}{c}{ Keturunan hipertensi } \\
kelamin & Ya & Tidak \\
\hline Laki-laki & 12 & 10 \\
Perempuan & 8 & 10 \\
Total & 20 & 20 \\
\hline
\end{tabular}

Tabel 2. Kadar asam urat subyek keturunan hipertensi dan bukan keturunan hipertensi

\begin{tabular}{ccc}
\hline Asam urat & $\begin{array}{c}\text { Keturunan hipertensi } \\
\text { Ya }\end{array}$ & Tidak \\
\hline Hiperurisemia & 6 & 3 \\
Normal & 14 & 17 \\
Total & 20 & 20 \\
\hline
\end{tabular}

\section{BAHASAN}

Studi potong lintang, kohort, dan intervensi terbaru telah mengidentifikasi hiperurisemia sebagai faktor risiko independen untuk hipertensi. Meski beberapa penelitian telah melaporkan hubungan antara kadar asam urat serum dan hipertensi, kelompok kadar asam urat serum tinggi banyak termasuk dalam kelompok dengan obesitas, diabetes, dan dislipidemia. Selanjutnya, obat-obatan mudah memengaruhi kadar asam urat serum. Karena kehadiran banyak faktor perancu, efek asam urat dianggap sulit diartikan. Laporan terbaru mengenai asam urat dan hipertensi berusaha untuk mengecualikan faktor-faktor pengganggu seperti itu sebanyak mungkin, dan uji intervensi double-blind juga dilakukan dengan menggunakan obat untuk menunjukkan hubungan antara asam urat dan hipertensi. ${ }^{11}$

Hasil penelitian ini mendapatkan kadar asam urat serum tinggi (hiperurisemia) pada subyek keturunan hipertensi sebanyak enam orang $(30 \%)$, sedangkan pada subyek tidak keturunan hipertensi sebanyak tiga orang (15\%). Pada tahun 2006, Heinig dan Johnson $^{12}$ melakukan studi eksperimental pada tikus untuk mengetahui hubungan hiperurisemia dan hipertensi. Pada studi tersebut, tikus diberi oxonic acid, suatu inhibitor uricase. Ketika uricase dihambat, asam urat tidak dapat diubah menjadi allantoin yang bersifat lebih larut dan dapat diekskresi melalui urin. Ternyata setelah 3-
5 minggu terjadi peningkatan tekanan darah tikus. Mekanisme hiperurisemia dalam menimbulkan hipertensi melibatkan dua jalur utama yaitu melalui aktivasi sistem renin angiotensin dan disfungsi endotel. ${ }^{12,13}$

\section{SIMPULAN}

Subyek dengan keturunan hipertensi lebih banyak mengalami hiperurisemia dibandingkan subyek tidak keturunan hipertensi, dengan jenis kelamin laki-laki pada kedua kelompok.

\section{Konflik Kepentingan}

Penulis menyatakan tidak terdapat konflik kepentingan dalam studi ini.

\section{DAFTAR PUSTAKA}

1. Whelton PK, Carey RM, Aronow WS, Casey DE, Collins KJ, Himmelfarb CD, et al. ACC/AHA/AAPA/ABC/ACPM/ AGS/APhA/ASH/ASPC/ NMA/PCNA guideline for the prevention, detection, evaluation, and management of high blood pressure in adults: a report of the American College of Cardiology/ American Heart Association Task Force on Clinical Practice Guidelines. Hypertension. 2018;71(6):1269-324.

2. Kearney PM, Whelton M, Reynolds K, Muntner P, Whelton PK, He J. Global burden of hypertension: analysis of worldwide data. Lancet. 2005;365:217-23.

3. WHO. Hypertension. [cited 2019 Aug 18. Available from: https://www.who.int/ news-room/fact-sheets/detail/ hypertension

4. Kementerian Kesehatan RI. Laporan Hasil Riset Kesehatan Dasar (Riskesdas) Nasional 2013. Jakarta: Badan Litbang Kesehatan. Kementerian Kesehatan RI. 2013.

5. Kementerian Kesehatan RI. Laporan Hasil Riset Kesehatan Dasar (Riskesdas) Nasional 2018. Jakarta: Badan Litbang Kesehatan. Kementerian Kesehatan RI. 2018

6. Maruhashi T, Hisatome I, Kihara Y, Higashi Y. Hyperuricemia and endothelial function: from molecular background to clinical perspectives. Atherosclerosis. 2018;278:226-31

7. Puddu P, Puddu GM, Cravero E, Vizioli L, Muscari A. The relationships among hyperuricemia, endothelial dysfunction, and cardiovascular diseases: molecular 
mechanisms and clinical implications. $\mathrm{J}$ Cardiol. 2012;59(3):235-42.

8. Zhen H, Gui F. The role of hyperuricemia on vascular endothelium dysfunction. Biomed Rep. 2017;7(4):325-30.

9. Cai W, Duan XM, Liu Y, Yu J, Tang YL, Liu $\mathrm{ZL}$, et al. Uric acid induces endothelial dysfunction by activating the HMGB1/ RAGE signaling pathway. BioMed Res Int. 2017;2017:4391920.

10. Feig D, Mazzali M, Kang D, Nakagawa T, Price K, Kannelis J, Johnson R. Serum uric acid: a risk factor and a target for treatment? JASN. 2006;17(4):S69-73.

11. Kim IY, Lee DW, Lee SB, Kwak IS. The role of uric acid in kidney fibrosis: experimental evidences for the causal relationship. Biomed Res Int. 2014;2014: 638732.

12. Heinig M, Johnson RJ. Role of uric acid in hypertension, renal disease, and metabolic syndrome. Clevel Clin J Med. 2006;73(12):1059-64.

13. Feig DI, Kang D-H, Johnson RJ. Uric acid and cardiovascular risk. New Eng J Med. 2008;359(17):1811-21 